\title{
AKIBAT HUKUM SUMPAH LI'AN YANG TIDAK TERBUKTI KEBENARANNYA TERHADAP STATUS ANAK BERDASARKAN HUKUM ISLAM DAN PERUNDANG-UNDANGAN
}

\author{
Hazar Kusmayanti \\ Fakultas Hukum \\ Universitas Padjadjaran \\ Bandung \\ hazar.kusmayanti@unpad. \\ ac.id
}

\begin{abstract}
The journey of living in a household does not always go as it should. If the household has a condition that is no longer aligned, then there is most likely a dispute that leads to divorce. Often divorce occurs because the father doubts his son,or because his wife commits adultery. When this happens, the husband can swear li'an which results in breaking the marriage and the relationship with his son. This study intends to examine the legal consequences of a child in the event of divorce due to li'an oath when the allegations of adultery are not proven to be true. This Research method uses normative juridical. The results showed that if it turns out that the swearing statement uttered by the husband is not proven to be true, then the divorce becomes void. Li'an's divorce was decent by his father's son as a result of li'an's divorce. The son is returned to his father, so that he again raises the rights and obligations between the child and the father.
\end{abstract}

Keywords: li'an vows, decent, li'an divorce.

\begin{abstract}
Abstrak: Perjalanan hidup berumah tangga tidak selalu mulus, terkadang badai menerpa. Jika rumah tangga memiliki kondisi yang tidak selaras lagi, maka kemungkinan besar terjadi perselisihan yang berujung pada perceraian. Seringkali perceraian terjadi karena ayah meragukan nasab anaknya, atau karena istrinya berzina. Ketika hal ini terjadi, maka suami dapat melakukan sumpah li'an yang berakibat memutus hubungan perkawinan dan hubungan nasab dengan anaknya. Penelitian ini bermaksud mengkaji akibat hukum anak jika terjadi perceraian karena sumpah li'an padahal tuduhan perzinahan itu tidak terbukti
\end{abstract}


kebenarannya. Metode Penelitian ini menggunakan yuridis normatif. Hasil penelitian menunjukkan, bahwa apabila ternyata pernyataan sumpah yang diucapkan oleh suami itu tidak terbukti kebenarannya, maka perceraian menjadi batal. Batalnya perceraian karena li'an membatalkan pula pengingkaran terhadap anak oleh ayahnya sebagai akibat hukum dari perceraian li'an. Anak menjadi dinasabkan kembali kepada ayahnya, sehingga kembali menimbulkan hak dan kewajiban antara anak dan ayah.

Kata Kunci: sumpah li'an, nasab anak,

\section{Pendahuluan} perceraian li'an.

Manusia menurut kodratnya diciptakan oleh Tuhan Yang Maha Esa dengan dua peranan, yaitu sebagai makhluk individu dan sebagai makhluk sosial. Manusia dengan perannya sebagai makhluk sosial akan selalu hidup bersama dengan manusia lainnya di dalam suatu pergaulan hidup, baik untuk memenuhi kebutuhan jasmani maupun rohani.1 Hubungan tersebut dapat dibangun melalui hubungan antar lawan jenis, yaitu melalui hubungan perkawinan. Pada umumnya, seorang pria maupun seorang wanita memiliki kebutuhan untuk hidup bersama melalui ikatan perkawinan. Perkawinan merupakan salah satu peristiwa penting dalam kehidupan manusia. Allah telah menciptakan segala makhluk dalam bentuk berpasangpasangan sebagaimana firman Allah: "Dan segala sesuatu kami ciptakan berpasang-pasangan".2

Perkawinan antara perempuan dan laki-laki menghindarkan keduanya dari perbuatan yang dilarang oleh agama, yaitu zina. Pernikahan menjaga kehormatan suami istri tetap terjaga. Ikatan lahir batin antara laki-laki dan perempuan

\footnotetext{
1 Hazar Kusmayanti, Eidy Sandra, Rijalullah Rahmatullah, "Kebsahan Perkawinan Kuli Kawin di Desa Pamanukan Hilir Kabupaten Subang diHubungkan Dengan Undang-undang Perkawinan No. 1 Tahun 1974 dan Hukum Islam", Suloh: Jurnal Fakultas Hukum Universitas Malikussaleh, Vol. 7, No. 2, April 2019, 1

2 QS. al-Dzariyat, (51): 49.
} 
yang terjalin melalui perkawinan merupakan salah satu bentuk perikatan sebagai perbuatan hukum. Dalam hukum Islam, perkawinan bukan hanya soal kenikmatan biologis. Menurut ArRum ayat 21, tujuan perkawinan adalah untuk membentuk satu keluarga yang bersatu, mawaddah, warrahmah. Perkawinan dalam tata hukum Indonesia yang positif diatur dalam UndangUndang Nomor 1 Tahun 1974 tentang Perkawinan, (selanjutnya disebut UU Perkawinan). Menurut Pasal 1 UU Perkawinan, perkawinan adalah ikatan jasmani dan rohani antara laki-laki dan perempuan sebagai suami-istri dengan tujuan membentuk keluarga (rumah tangga) bahagia dan langgeng berdasarkan Ketuhanan Yang Maha Esa. UU Perkawinan menyatakan bahwa perkawinan dianggap sah jika sesuai dengan hukum agama masing-masing. Sehingga hukum yang berlaku dalam perkawinan yang dilakukan oleh warga negara Indonesia adalah hukum agama dan kepercayaannya masing-masing.3

Bentuk Pengakuan Hukum Islam di Indonesia tertuang dalam Intruksi Presiden No. 1 Tahun 1991 Tentang Kompilasi Hukum Islam (selanjutnya disebut KHI) dan dijadikan acuan bagi masyarakat Indonesia yang beragama Islam. Perkawinan sebagai salah satu ranah hukum Islam berdasarkan KHI memiliki pengertian sebagai akad yang sangat kuat atau mitssaqan ghalidzan untuk menaati perintah dan melaksanakannya merupakan ibadah. Salah satu asas nikah adalah asas kekal, yang menunjukkan bahwa perkawinan dilaksanakan untuk melaksanakan keturunan dan membina cinta dan kasih sayang selama hidup dan karena itu pula nikah mut'ah, yaitu perkawinan sementara untuk bersenang-senang selama waktu tertentu, dilarang oleh Nabi Muhammad. Tujuan perkawinan menurut hukum Islam terdiri dari:4

1. Berbakti kepada Allah;

3 Hazar Kusmayanti dkk, "Divorce Caused By Hypersexual Pshological Disorders In Husband”, Jurnal Nurani, Vol. 19 No. 1 Desember, 2019, 162.

4 Santoso, " Hakekat Perkawinan Menurut Undang-undang Perkawinan, Hukum Islam dan Hukum Adat”, YUDISIA, Vol. 7, No. 2, Desember 2016, 417 
2. Memenuhi atau mencukupkan kodrat hidup manusia yang telah menjadi hukum bahwa antara pria dan wanita saling membutuhkan;

3. Mempertahankan keturunan umat manusia

4. Melanjutkan perkembangan dan ketentraman hidup rohaniah antara pria dan wanita;

5. Mendekatkan dan saling menimbulkan pengertian antar golongan manusia untuk men jaga keselamatan hidup

Kelima tujuan perkawinan ini didasarkan kepada QS. ArRum, (30): 21 yang menyatakan bahwa,

"Ia jadikan bagi kamu dari jenis kamu, jodoh-jodoh yang kamu bersenang-senang kepadanya, dan ia jadikan di antara kamu percintaan dan kasih sayang sesungguhnya hal itu menjadi bukti bagi mereka yang berfikir".5

Di Indonesia, Perkawinan sah secara negara apabila perkawinan tersebut dilakukan menurut hukum agamanya dan kepercayaan itu. Tiap-tiap perkawinan dicatat menurut peraturan perundang-undangan yang berlaku. 6

Terdapat 6 asas yang sangat prinsipil dalam Undangundang Perkawinan, di antaranya sebagai berikut:

1. Tujuan perkawinan adalah membentuk keluarga yang bahagia dan kekal. Untuk itu suami istri perlu saling membantu dan melengkapi agar masing-masing dapat mengembangkan kepribadiannya, membantu dan mencapai kesejahteraan spiritual dan material.

2. Dalam undang-undang ini ditegaskan, bahwa suatu perkawinan adalah sah apabila dilakukan menurut hukum masing-masing agamanya dan kepercayaannya itu, dan disamping itu tiap-tiap perkawinan "harus dicatat" menurut peraturan perundang-undangan yang berlaku.

3. Undang-undang ini menganut asas monogami. Hanya apabila ia dikehendaki oleh yang bersangkutan, karena hukum dan

5 Abdul Majid Mahmud Mathlub, Panduan Hukum Keluarga Sakinah, Intermedia, Solo, 2005, 78-80

6 Ahmad Rafiq, Hukum Islam di Indonesia, PT. RajaGrafindo, Jakarta, 2000, 5657. 
agama dari yang bersangkutan mengijinkan seorang suami dapat beristri lebih dari seorang.

4. Undang-undang perkawinan ini menganut prinsip, bahwa calon suami istri harus telah masak jiwa raganya untuk dapat melangsungkan perkawinan, agar dapat mewujudkan tujuan perkawinan dan mendapat keturunan yang baik dan sehat.

5. Karena tujuan perkawinan adalah untuk membentuk keluarga yang bahagia, kekal, dan sejahtera, maka undangundang ini menganut prinsip untuk mempersulit terjadinya perceraian.

6. Hak dan kedudukan istri adalah seimbang dengan hak dan kedudukan suami, baik dalam kehidupan rumah tangga maupun dalam pergaulan masyarakat, sehingga dengan demikian segala sesuatu dalam keluarga dapat dirundingkan dan diputuskan bersama oleh suami istri

Tetapi tujuan perkawinan tersebut menjadi tidak tercapai ketika kehidupan dalam rumah tangga tidak selalu berjalan mulus, pertengkaran dan percekcokan sering terjadi karena berbagai hal. Problem yang tidak teratasi dalam rumah tangga ini seringkali berujung pada perceraian. Perceraian merupakan perkara yang diperbolehkan oleh Allah SWT, tetapi sekaligus menjadi hal yang sangat dibenci oleh-Nya, sesuai dengan perkataan Nabi Muhammad SAW, bahwa perbuatan yang paling dibenci Allah Swt. adalah perceraian. 7

Banyak sekali alasan pasangan bercerai, selain tidak memiliki anak, alasan perceraian lainnya adalah karena kekerasan dalam rumah tangga. Juga karena ditinggal suami bertahun-tahun, seperti yang terjadi pada beberapa subjek penelitian. Hal ini dibenarkan dalam undang-undang di Indonesia.s Konflik yang sering terjadi dalam masyarakat antara suami dan istri yang menyebabkan perceraian atau hubungan

7 Ibnu Majah, Sunan Ibnu Majah, juz 1 bab Talak, hadis ke-2018, 650.

8 Nurhasanah, "The Analysis of Causes of Divorce by Wives", The International Journal of Counseling and Education, Vol. 2 , 2017, 195. 
tidak harmonis antara keduanya. Di antara penyebab perceraian adalah li'an yang dilakukan suami terhadap istrinya.9

Al-Quran juga memberi peluang untuk bercerai bagi pasangan yang kemungkinan besar tidak dapat menjaga kelangsungan rumah tangga. Hal ini menunjukkan bahwa pada dasarnya perceraian diperbolehkan, namun alangkah baiknya jika dicarikan jalan keluarnya terlebih dahulu agar perceraian dapat dihindari. Nabi Muhammad SAW bersabda:

"Perkawinan itu dapat menundukkan pandangan (menjauhi mata keranjang) dan lebih menjaga kehormatan (menghindari zina)".10

Zaman yang semakin berkembang dan pergaulan yang semakin bebas seringkali mengakibatkan perselingkuhan dan perzinahan, baik dilakukan oleh istri maupun suami. Zina menurut Kamus Besar Bahasa Indonesia (KBBI) adalah perbuatan bersetubuh antara laki-laki dan perempuan yang tidak terikat hubungan perkawinan (nikah); tindakan bersetubuh dengan pria yang menikah dengan wanita yang bukan istrinya, atau wanita yang menikah dengan pria yang bukan suaminya. Menurut ahli hukum aliran Hanafi, zina adalah hubungan seksual yang dilakukan oleh laki-laki secara sadar terhadap perempuan dengan disertai nafsu seksual dan di antara mereka tidak ada perkawinan yang sah, atau perkawinan mereka diragukan kebenaran dan keabsahannya, seperti ikatan nikah tanpa wali nikah, tanpa saksi, atau nikah mut'ah. 11 Zina adalah dosa terbesar ketiga setelah kafir dan membunuh.12 Zina menjadi salah satu pemicu keretakan hubungan rumah tangga yang bisa berujung pada perceraian. Islam melarang perzinahan dan karena itu memerintahkan umat Islam untuk menjauhkan diri dari semua godaan setan yang akan mendorong seseorang

9 Agoes Dariyo, "Memahami Psikologi Perceraian dalam Kehidupan Keluarga”, Jurnal Psikologi, 2, No. 2, 2004, 94-100.

10 Neng Djubaedah, Perzinaan dalam Peraturan Perundang-undangan di Indonesia Ditinjau dari Hukum Islam, (Jakarta: Kencana, 2010), 119.

11 Awy A. Qolawun, Islam Q \& A: Dari Seks pada Rumah Tangga Hingga Bohong pada Suami, (Jakarta: Mizania, 2015), 145.

12 Ibid.,147. 
untuk melakukan zina. 13 Jika sebuah perkawinan telah ternoda oleh zina, maka dapat menimbulkan keraguan terhadap sang anak.14 Pengingkaran ayah terhadap anak akan berdampak langsung pada kedudukan istri dan anak. Namun jika hal ini terjadi, maka suami dapat menceraikan istrinya dengan li'an, yaitu cerai dengan alasan istrinya telah berzina dengan pria lain.

Sebetulnya penelitian tentang perceraian karena Li'an ini telah dilakukan oleh beberapa orang peneliti sebelumnya yaitu diantaranya Riswan Munthe 15 mengenai Kekuatan Sumpah Li'an Menurut Fiqh Islam, Suryani 16 mengenai Li'an Dalam Perpektif Filosofis dan Normatif, dan Anwar Hafidzi17 yang meneliti tentang Penolakan Nasab Anak Li'an dan Zihar dengan Ta'liq.

Penelitian yang akan peneliti bahas berbeda dengan penelitian yang telah dilakukan oleh beberapa peneliti di atas yang lebih meneliti Li'an dalam perspektif Hukum Islam. Kajian yang akan peneliti bahas, bagaimana akibat hukum anak jika terjadi perceraian karena li'an, padahal tuduhan perzinahan yang diajukan suami kepada istrinya belum tentu terbukti kebenarannya menurut Hukum Islam dan Peraturan perundang-undangan di Indonesia.

Pendekatan yang digunakan dalam tulisan ini adalah yuridis normatif, yaitu mengkaji dan menganalisis akibat hukum anak jika terjadi perceraian karena li'an padahal tuduhan perzinahan yang diajukan suami kepada istrinya tidak terbukti kebenarannya menurut Hukum Islam dan Hukum positif.1 Teknik analisis yang digunakan digunakan adalah deskriptif analitis, yaitu menjelaskan ketentuan yang berkaitan erat

13 Abdur Rahman I. Doi, Inilah Syariah Islam, (Jakarta: Pustaka Panji Mas, 1991), 342.

14 Maswandi, “Asuh Anak yang Belum Dewasa Setelah Perceraian”, JPPUMA: Jurnal Ilmu Pemerintahan dan Sosial Politik, Vol. 5 (1) 2017, 21.

15 Riswan Munthe, "Mengenai Kekuatan Sumpah Lian Menurut Fiqh Islam", Jurnal Penegakan Hukum, Vol 3, No 1 (2016), 44-49.

16 Suryani, "Lian Dalam Perpektif Filosofis dan Normatif", Jurnal Pemikiran Keislaman dan Tafsir Hadist, Vol 5, No 1 (2016).

17 Anwar Hafidzi, Binti Musyarrofah, "Penolakan Nasab Anak Li'an dan Dhihar dengan Ta'liq (Analisis Komparatif Naskah Kitab Fiqh al-Islām wa Adillatuhu dengan al-Mughni)", Jurnal Ulul Albab, Vol. 1, No. 2, April 2018,77-94. 
dengan tema yang dipilih oleh peneliti, yaitu masalah akibat hukum anak jika terjadi perceraian karena li'an padahal tuduhan perzinahan yang diajukan suami kepada istrinya tidak terbukti kebenarannya menurut Hukum Islam dan Hukum Perkawinan Indonesia. 18

\section{Perceraian dalam Hukum Islam dan Hukum Positif}

Perkawinan merupakan salah satu kebutuhan manusia, karena sifat dasar manusia yang selalu berkeinginan untuk hidup berkelompok. Perkawinan bertujuan untuk melestarikan keturunan. Menurut UU Perkawinan, perkawinan bertujuan untuk membentuk keluarga yang bahagia dan kekal berdasarkan Ketuhanan Yang Maha Esa. Sedangkan menurut Kompilasi Hukum Islam, perkawinan bertujuan untuk mewujudkan kehidupan rumah tangga yang sakinah, mawaddah, dan rahmah.

Suatu keluarga akan terasa sangat lengkap apabila telah dikarunia anak oleh Allah SWT. Anak merupakan karunia dari Allah SWT kepada kedua orang tuanya, yang harus dirawat dengan penuh kasih sayang. Apabila terjadi pertengkaran dalam suatu keluarga, apalagi jika sampai terjadi perceraian, maka anak merupakan pihak yang paling menderita pula. Anak adalah individu yang perlu dilindungi karena sifatnya yang lemah dan masih belum bisa mendapatkan hak-hak sepenuhnya yang dimiliki oleh orang yang telah dewasa.

Suatu perkawinan yang kerap terjadi pertengkaran di dalamnya, yang dapat disebabkan oleh berbagai macam hal dapat memicu timbulnya perceraian. Perceraian adalah akhir dari sebuah pernikahan. Jika kedua pasangan tidak ingin melanjutkan kehidupan pernikahannya, mereka dapat mengajukan permohonan perceraian. Selama perceraian, pasangan harus memutuskan bagaimana membagi harta mereka yang diperoleh selama pernikahan, dan bagaimana

18 Soerjono Soekanto, Pengantar Penelitian Hukum, (Jakarta: UI-Press, 2011), 52. 
mereka menerima biaya dan kewajiban mengasuh anak-anak mereka.19

\section{Perceraian Menurut Hukum Islam dan Peraturan Perundang-undangan}

Perceraian di Indonesia, menurut hukum Islam yang telah dipositifkan dalam Pasal 38 dan Pasal 39 Undang-undang No. 1 Tahun 1974 Tentang Perkawinan dan telah dijabarkan dalam Peraturan Pemerintah Nomor 9 Tahun 1975 Tentang Peraturan Pelaksana mencakup cerai talak yang perceraiannya diajukan oleh suami kepada pengadilan agama dan cerai gugat yang percerainnya diajukan oleh isteri kepada Pengadilan Agama. Sedangkan perceraian menurut hukum selain hukum Islam, yaitu gugatan cerainya diajukan oleh dan atau inisiatif suami atau isteri kepada pengadilan negeri.20

Perceraian sebagai salah satu perbuatan halal yang paling dibenci oleh Allah dapat disebabkan oleh berbagai macam hal, berdasarkan UU Perkawinan dan PP Perkawinan, yaitu:

1. Salah satu pihak berbuat zina atau menjadi pemabuk, pemadat, penjudi dan lain sebagainya yang sukar disembuhkan;

2. Salah satu pihak meninggalkan yang lain selama 2 (dua) tahun berturut-turut tanpa izin pihak lain dan tanpa alasan yang sah atau karena hal lain-lain di luar kemauannya;

3. Salah satu pihak mendapat hukuman penjara 5 (lima) tahun atau hukuman yang lebih berat setelah perkawinan berlangsung;

4. Salah satu pihak melakukan kekejaman atau penganiayaan berat yang membahayakan terhadap pihak lain;

19 Zahri Hamid, Pokok-pokok Hukum Perkawinan Islam dan Undang-Undang Perkawinan di Indonesia, (Yogyakarta: Bina Cipta, 2002),4

20 Hazar Kusmayanti dkk, "Keabsahan Perkawinan Kuli Kawin di Desa Pamanukan Hilir Kabupaten Subang Dihubungkan dengan Undang-undang Perkawinan dan Hukum Islam", Suloh: Jurnal Fakultas Hukum Universitas Malikussaleh, Vol. 7, No. 2, April 2019, 3. 
5. Salah satu pihak mendapat cacat badan atau penyakit yang mengakibatkan tidak dapat menjalankan kewajibannya sebagai suami atau istri;

6. Antara suami dan istri terus-menerus terjadi perselisihan dan pertengkaran dan tidak ada harapan akan hidup rukun lagi dalam rumah tangga.

Pada KHI terdapat dua ketentuan tambahan, yaitu apabila suami melanggar taklik talak dan apabila salah satu pihak murtad. Berdasarkan ketentuan pada UU Perkawinan di atas maka salah satu alasan perceraian adalah karena zina. Zina adalah perbuatan bersanggama antara laki-laki dan perempuan yang tidak terikat oleh hubungan pernikahan (perkawinan); perbuatan bersanggama seorang laki-laki yang terikat perkawinan dengan seorang perempuan yang bukan istrinya, atau seorang perempuan yang terikat perkawinan dengan seorang laki-laki yang bukan suaminya. Pada Hukum Islam, pelaku zina tersebut dibedakan menjadi pelaku zina yang belum kawin atau masih perawan atau perjaka yang disebut gairu muhșan atau gairu muhșanah dan pelaku zina yang telah kawin yang disebut muhșan atau muhșanah.

Dalam Islam, pasca perceraian, ada persoalan terkait pengasuhan anak yang disebut dengan haḍānah. Menurut ulama fiqh, hadānah adalah mengasuh anak yang masih muda, baik laki-laki maupun perempuan, atau yang berbadan besar tetapi belum mumayyiz, memberikan sesuatu untuk kebaikannya, mendidik jasmani, rohani dan akal budi agar mampu berdiri tegak sendirian menghadapi hidup dan memikul tanggung jawab. Anak pada permulaan hidupnya sampai umur tertentu memerlukan orang lain atau yang disebut dengan pengasuhan (hadōnah) biasanya apabila terjadi perceraian hak hadananh bagi anak yang belum mumayyiz otomatis ke asuhan ibunya.21 Ayah juga berkesempatan untuk mengasuh anak, meskipun pada derajat yang lebih jauh dibandingkan ibu. Pasal 156 huruf (a) KHI menyebutkan "anak yang belum mumayyiz berhak

21 Elimartati, Firdaus, "Hak Hadanah dalam Putusan Pengadilan", Jurnal Syariah, No. 2, Juli-Desember 2018, 234. 
mendapatkan hadhanah dari ibunya, kecuali bila ibunya telah meninggal dunia, maka kedudukannya digantikan oleh:22

1. Wanita-wanita dalam garis lurus ke atas dari ibu

2. Ayah

3. Wanita-wanita dalam garis lurus ke atas dari ayah

4. Saudara perempuan dari anak yang bersangkutan

5. Wanita-wanita kerabat sedarah menurut garis samping dari ayah.

\section{Pengingkaran Anak dan Sumpah Lian dalam Hukum Islam dan Hukum Positif}

Lalu bagaimana apabila ayah tidak mengakui nasab anaknya karena menuduh ibu sang anak Lian?

Adapun mengenai syarat penolakan nasab anak, menurut madzhab Hanafi seperti dikutip oleh Anwar Hafidzi, terdapat enam syarat: 23

1. Keputusan qādi untuk memisahkan suami-istri.

2. Penolakan nasab anak dilakukan langsung setelah kelahiran, atau satu atau dua hari sesudahnya, atau sampai tujuh hari yang biasanya merupakan waktu pemberian ucapan selamat.

3. Tidak ada pengakuan darinya mengenai pengakuan nasab anak walaupun hanya berupa isyarat, seperti penerimaannya terhadap ucapan selamat atas kelahiran anak.

4. Si anak dalam keadaan hidup waktu saat perceraian hukum.

5. Jangan sampai lahir anak yang lain dari satu perut setelah terjadinya pemisahan.

6. Tidak dikenakan hukuman dengan penetapan nasab anak secara syariat.

Adanya zina dalam hubungan perkawinan ini dapat menimbulkan keraguan suami kepada istrinya yang sedang

22 Mansari, "Pertimbangan Hakim Memberikan Hak Asuh Kepada Ayah : Suatu Kajian Empiris di Mahkamah Syariah Banda Aceh", Jurnal Ar-raniry, Vol. 1 Nomor 1, April 2016, 91.

23 Anwar, Op.cit, 87 
mengandung atau bahkan telah melahirkan anak. Keraguan suami yang tidak dapat membuktikan bahwa istrinya telah berzina dengan mendatangkan empat orang saksi ini dapat diteguhkan melalui sumpah li'an, yaitu sumpah suami yang berisi tuduhan bahwa istrinya telah berzina dan anak yang dikandung atau telah dilahirkan tersebut bukanlah anaknya. Sayyid Sabiq berkata:24

"Jika suami melihat istrinya berzina dengan laki-laki lain lebih baik dia menalak istrinya, bukan melakukan li'an, tetapi jika tidak terbukti laki-laki lain yang menzinainya maka suami boleh menuduhnya berbuat zina dan boleh tidak mengakui kehamilan istrinya, biar dalam keadaan bagaimanapun karena ia merasa sama sekali belum pernah mencampuri istrinya sejak akad nikahnya, atau ia merasa mencampuri istrinya, tetapi baru setengah tahun sedangkan umur kandungannya tidak sesuai dengan usia pernikahannya."

Menurut bahasa, li'an adalah mașdar dari al-lä'in seperti alqātil yaitu pengusiran dan penjauhan dari rahmat Allah SWT. Dinamakan dengan li'an karena apa yang terjadi antara suami dan istri. Sebab masing-masing mereka melaknat dirinya sendiri pada kali kelima jika dia berdusta atau suami yang melaknat dirinya sendiri jika ia berdusta. Pada dasarnya, saling melaknat ini muncul akibat dari hubungan suami istri yang saling mencurigai dan menuduh tanpa ada dasar yang jelas.25 Pada akhirnya saling memunculkan pernyataan yang saling menyalahkan antara suami dan istrinya. 26

Pengertian sumpah sesuai dengan yang dirumuskan oleh Sudikno Mertokusumo, sebagaimana dikutip oleh Chatib Rasyid

24 Zainal Muttaqin, “Tinjauan Yuridis Perceraian Li'an Menurut Hukum Islam dan Undang-Undang No. 1 Tahun 1974 Tentang Perkawinan”, (Skripsi-Fakultas Hukum, UNPAD, 2013), 89.

25Zaisika,https://media.neliti.com/media/publications/14077-IDperceraian-karena-lian-dan-akibat-hukum-dalam-perspektif-fiqih-islamdan-kompila.pdf, diakses (01/11/2020)

26 Nurul Afifah, "Qadzaf Menurut Hukum Islam dan KHI," Istinbath: Jurnal Hukum, 12, No. 1 (2015),155. 
dan Syaifuddin, adalah pernyataan khusyuk yang diberikan atau diucapkan ketika memberikan janji atau keterangan dengan mengingat kodrat Yang Maha Kuasa Tuhan dan meyakini bahwa yang memberi informasi atau janji palsu akan dihukum olehNya.27 Menurut M. Yahya Harahap, sumpah sebagai alat bukti adalah pernyataan yang dikuatkan atas nama Tuhan YME, dengan tujuan agar orang yang bersumpah dalam memberikan pernyataan, takut kepada Tuhan jika dia berbohong; Takut akan murka atau hukuman Tuhan, dianggap sebagai kekuatan pendorong bagi mereka yang bersumpah untuk menjelaskan kebenaran.28

Pelafalan sumpah li'an dilakukan secara runut sesuai dengan ketentuan dalam al-Quran. Sumpah tersebut diucapkan oleh suami sebanyak empat kali dengan lafal sebagai berikut:

"Wallāhi, Demi Allah saya bersumpah bahwa bahwa istri saya telah berbuat zina."

suami kemudian mengangkat sumpahnya yang kelima dengan lafal:

"Saya siap menerima laknat Allah apabila saya berdusta."

Istri pun mengangkat sumpahnya sebagai bentuk bantahan atas tuduhan suami terhadapnya sebanyak empat kali dengan lafal sebagai berikut:

"Wallāhi, Demi Allah saya bersumpah bahwa saya tidak berbuat zina,"

kemudian diikuti dengan sumpahnya yang kelima, yaitu: "Saya siap menerima murka Allah apabila saya berdusta."

Kuasa sumpah li'an, menurut yurisprudensi Islam, membuat suami-istri haram untuk dipersatukan kembali. Jika sumpah li'an sudah diucapkan, maka mantan suami istri tidak dibenarkan untuk rujuk di masa iddah, juga tidak dibenarkan untuk kembali menikah bahkan dengan perjanjian pernikahan baru. Baik suami maupun istri harus mencari pasangan lain

27 Chatib Rasyid, Syaifuddin, Hukum Acara Perdata dalam Teori dan Praktik pada Peradilan Agama, (Yogyakarta: UII Press, 2009), 113-111.

28 M. Yahya Harahap, Hukum Acara Perdata Tentang Gugatan, Persidangan, Penyitaan, Pembuktian, dan Putusan Pengadilan, (Jakarta: Sinar Grafika 2010), 745. 
meskipun dalam keadaan penuh penyesalan.29 Li'an merupakan perceraian yang cara penjatuhannya adalah melalui ucapan atau perkataan. Perceraian ini tergolong ke dalam talak $b \bar{a}^{\prime}$ in $k u b r a$ atau talak $b \bar{a}^{\prime} i n$ besar karena setelah penjatuhan talak ini maka suami istri tersebut tidak dapat rujuk kembali sebelum mantan istri menikah kembali dengan orang lain. Hal ini sejalan dengan Pasal 125 KHI yang menyatakan, bahwa li'an menyebabkan putusnya perkawinan antara suami istri untuk selama-lamanya. Berdasarkan Pasal 163 ayat (2) KHI pun menyatakan, bahwa perceraian dengan alasan zina tidak dapat dirujuk kembali.

Tuduhan zina terhadap seseorang harus dilandaskan kepada bukti-bukti yang kuat, karena tuduhan semacam itu sangat berbahaya apabila tidak didukung oleh bukti dan fakta, karena akan sangat mencoreng nama baik seseorang. Terlebih lagi untuk membersihkan nama baik setelah adanya fitnah, tidaklah mudah karena fitnah dapat menyebar dengan sangat cepat tanpa dapat dikendalikan. Itulah sebabnya mengapa Allah sangat mengutuk orang yang qadaf, yang menuduh seseorang yang bersih dan beriman telah berzina.

Li'an baru dapat terlaksana apabila telah memenuhi syarat wajib dan syarat sahnya li'an. Syarat wajib li'an meliputi:

1. Pasangan tersebut masih berstatus suami istri, sekalipun istri belum digauli atau istri masih dalam masa idah talak raj'i. Akan tetapi, jumhur ulama menyatakan bahwa li'an tetap sah terhadap istri yang dalam talak $b \bar{a}^{\prime} i n$;

2. Status perkawinan mereka adalah nikah yang sah, tetapi menurut pendapat kalangan jumhur ulama li'an juga sah dilakukan dalam nikah fäsid (nikah tanpa wali ataupun nikah tanpa saksi) karena adanya masalah nasab (keturunan) dalam nikah fäsid tersebut;

3. Suami adalah seorang muslim yang cakap dalam memberikan kesaksian secara lisan. Kalangan ulama Mazhab Maliki mensyaratkan bahwa suami adalah

29 Suparman Usman, Hukum Islam Asas-Asas dan Pengantar Studi Hukum Islam dalam Tata Hukum Indonesia, (Jakarta: PT. Gaya Media Pratama, 2001), 18. 
harus seorang muslim, tetapi tidak bagi ulama Mazhab Syafi'i dan Hanbali karena yang menjadi patokan bagi mereka adalah bahwa suami adalah orang yang cakap menjatuhkan talak kepada istrinya;

4. Adanya tuduhan berbuat zina dari suami terhadap istri; dan

5. Istri mengingkari tuduhan tersebut sampai berakhirnya proses dan hukum li'an. meliputi:

Adapun syarat sahnya perceraian li'an di pengadilan

1. Li'an dilakukan di hadapan hakim;

2. Li'an dilaksanakan suami setelah diminta oleh hakim;

3. Lafal li'an yang lima kali diucapkan secara sempurna;

4. Lafal yang dipergunakan dalam li'an itu sesuai dengan yang dituntunkan Al-Quran;

5. Proses li'an harus berturut, dimulai dengan sumpah suami empat kali dan yang kelima suami melaknat dirinya, tidak boleh sebaliknya dan tidak boleh diubah; dan

6. Apabila kedua suami istri tersebut hadir dalam persidangan li'an maka keduanya boleh mengajukan isyarat untuk menunjuk pihak lainnya, tetapi jika ada di antara mereka yang tidak hadir, maka penunjukan harus dilakukan dengan penyebutan nama dan identitas lengkap.

\section{Akibat Hukum Sumpah Li'an Terhadap Status Anak}

Status Anak setelah sumpah li'an menjadi tidak ada lagi hubungan kekeluargaan dengan bapak yang melakukan sumpah li'an. Nasab anak tersebut diberikan kepada ibu yang melahirkan dan kedudukan anak tersebut berubah dari anak nikah menjadi anak luar nikah. Terjadinya penyangkalan anak, memutuskan hubungan kekeluargaan anak dengan bapak yang menyangkalnya, sehingga bapak tidak memiliki kewajiban kepada anak. Selain bebas dari kewajiban menafkahi sebagaimana dimaksud dalam Pasal 162 KHI, anak juga tidak 
lagi berhak mendapatkan warisan dari ayahnya. Anak-anak ini hanya dapat mewarisi dari ibu dan keluarga ibunya.30

Selain itu, syarat agar anak dapat di-li'an meliputi:31

1. Berdasarkan mazhab Abu Hanifah, proses pengingkaran nasab harus dilakukan secara langsung setelah istri melahirkan. Sejalan dengan pendapat tersebut, Mazhab Syafi'i pun menyatakan, bahwa langsung itu sebagai persyaratan, apabila tidak langsung maka syaratnya menjadi tidak lengkap;

2. Anak yang dilahirkan tersebut harus masih dalam keadaan hidup; dan

3. Pengingkaran tersebut harus dinyatakan secara tegas, tidak boleh ada keraguan.

Setelah sumpah li'an, anak diserahkan kepada ibunya, namun jika ternyata sang suami terbukti berbohong pada saat diambil sumpah li'an, maka larangan tersebut akan hilang dan mereka diperbolehkan untuk menikah lagi. Hal tersebut sesuai dengan pendapat Imam Abu Hanifah dalam kitab BadA'i alȘanā'i seperti dikutip oleh Zakariya Ahmad Al-Barry, : 32

"Abu Hanifah beralasan, karena suami telah mengakui kebohongan dalam tuduhannya, ini berarti sumpah li'annya dibatalkan, sama seperti suami boleh menyerahkan anakanaknya kepadanya, begitu pula istrinya jika suaminya menginginkannya. Karena dasar haram bagi mereka selamanya adalah belum bisa ditentukannya siapa yang benar dari pasangan suami istri, padahal jelas salah satu dari mereka pasti bohong. Oleh karena itu, jika rahasianya sudah terbongkar maka keabadiannya akan menjadi terhapus. "

Pembatalan cerai li'an antara suami istri karena penipuan atas sumpah, berakibat batalnya penyangkalan ayah atas penyangkalan anaknya, karena dasar penyangkalan itu adalah

30 Soedharyo Soimin, Hukum Orang dan Keluarga: Perspektif Hukum Perdata Barat/ BW, Hukum Islam, dan Hukum Adat, (Jakarta: Sinar Grafika. 2002), 25. 31 Fathurrohman (Bagian Fatwa MUI), Wawancara, Kantor MUI Jawa Barat, 26 Agustus 2020.

32 Zakariya Ahmad Al-Barry, Hukum Anak-Anak dalam Islam, (Jakarta: Bulan Bintang, 1997), 57. 
adanya sumpah li'an. Dengan batalnya sumpah li'an, maka penasaban seorang anak kepada ibunya karena li'an menjadi batal. Anak yang dikembalikan kepada ayahnya berhak untuk kembali menggunakan nama ayahnya, berhak mendapat dukungan dari ayahnya, berhak mendapat warisan dari ayah atau keluarganya, dan jika anak itu perempuan, maka ayahnya adalah wajib menjadi walinya. Semua hak dan kewajiban antara ayah dan anak yang sebelumnya dihapus karena li'an terulang kembali. Salah satu kewajiban seorang ayah yang tercantum dalam sabda Allah surat At-Talak ayat 7, yaitu:

Hendaklah orang yang mempunyai keluasan memberi nafkah menurut kemampuannya, dan orang yang terbatas rezekinya, hendaklah memberi nafkah dari harta yang diberikan Allah kepadanya. Allah tidak membebani kepada seseorang melainkan (sesuai) dengan apa yang diberikan Allah kepadanya. Allah kelak akan memberikan kelapangan setelah kesempitan.

Berdasarkan hasil wawancara yang penulis lakukan dengan Hakim Subhan Fauzi, di Kantor Pengadilan Agama Bandung, jika terbukti suami berbohong pada saat sumpah li'an, maka anak tersebut dapat diteguhkan kembali.33 Ayahnya harus mengajukan permohonan ke Pengadilan Agama dengan kasus penentuan usul anak asal. Hal ini karena pada dasarnya, perkara pokok dalam li'an adalah mengenai perceraian dan penyangkalan atau perubahan status pada anak hanya sebagai akibat hukum dari adanya perceraian li'an.

Sehubungan dengan asal usul anak ini diatur dalam Pasal 55 UU Perkawinan, yaitu:

(1) Asal usul anak hanya dapat dibuktikan dengan akta kelahiran asli yang diterbitkan oleh pejabat yang berwenang;

(2) Dalam hal akta kelahiran sebagaimana dimaksud pada ayat (1) pasal ini tidak ada, Pengadilan dapat menerbitkan penetapan mengenai asal usul anak

33 Subhan Fauzi (Hakim Pengadilan Agama Bandung), Wawancara, 2 Februari 2020. 
setelah dilakukan pemeriksaan secara cermat berdasarkan alat bukti yang memenuhi syarat.

KHI juga mengatur asal usul anak ini, yaitu pada Pasal 103 sebagai berikut:

(1) Asal usul anak hanya dapat dibuktikan dengan akta kelahiran atau alat bukti lain;

(2) Dalam hal akta kelahiran alat bukti lain sebagaimana dimaksud pada ayat (1) tidak ada, maka Pengadilan Agama dapat menerbitkan penetapan mengenai asal usul seorang anak setelah dilakukan pemeriksaan secara cermat berdasarkan alat bukti yang sah.

Sumpah li'an yang diikrarkan di muka pengadilan tidak hanya berdasarkan persangkaan belaka, melainkan harus pula didukung oleh bukti-bukti yang menguatkan telah terjadinya perzinaan yang dituduhkan tersebut. Bukti-bukti tersebut dapat berupa kemiripan anak yang diingkari dengan laki-laki lain yang dianggap telah berzina dengan istrinya, tes Deoxy Nucleated Acid (DNA), ataupun suami merasa bahwa kali terakhir dia menggauli istrinya tidak sesuai dengan umur kandungan istrinya. Apabila suami tidak dapat mengajukan bukti-bukti yang kuat terkait tuduhannya tersebut maka prasangka itu adalah dosa dan ia termasuk orang yang qadaf (menuduh zina), yang mana Allah sangat mengutuk perbuatannya ini, sebagaimana dalam firman Allah surat An-Nur ayat 23:

"Sesungguhnya orang-orang menuduh (berbuat zina) kepada perempuan yang bersih, jujur, beriman, mereka dikutuk di dunia dan di akhirat, dan bagi mereka azab yang besar."

Mengenai kapan suami-istri dipisahkan, para ahli Hukum Islam mengatakan, sejak selesainya pengucapan li'an maka sejak itu pula suami dan istri tersebut harus dipisahkan, namun sebagian lagi yang lain mengatakan bahwa terjadinya pemisahan suami istri itu sejak putusan pengadilan diucapkan oleh hakim.34 Adanya mulä'anah (saling melaknat) dengan cara

34 Abdul Manan, Penerapan Hukum Acara Perdata di Lingkungan Peradilan Agama, (Yogyakarta: Kencana, 2016), 465-466. 
li'an antar suami dan istri menimbulkan akibat hukum bahwa anak dinasabkan kepada ibunya.35 Hal ini sesuai dengan hadis Nabi Muhammad SAW sebagai berikut:36

"Sesungguhnya Nabi SAW menyaksikan li'an antara seorang laki-laki dan istrinya maka laki-laki itu tidak mengakui anak yang lahir dari istrinya itu maka beliau memisahkan di antara keduanya dan menghubungkan nasab anak kepada ibunya."

Hadis lain yang diriwayatkan oleh Imam Bukhori dan Imam Muslim menyebutkan:

"Anak itu haknya (laki-laki) yang memiliki tempat tidur dan bagi yang berzina tidak mempunyai hak apapun (atas anak tersebut)."

Pada Pasal 162 KHI pun dijelaskan mengenai kedudukan seorang anak setelah terjadinya li'an, yaitu:

"Bilamana li'an terjadi maka perkawinan itu putus untuk selamanya dan anak yang dikandung dinasabkan kepada ibunya, sedang suaminya terbebas dari kewajiban memberi nafkah."

Berdasarkan hukum positif, anak tergolong ke dalam dua golongan, yaitu anak sah dan anak tidak sah. Anak sah adalah anak yang dilahirkan dalam atau sebagai akibat dari perkawinan yang sah, seperti yang tercantum dalam Pasal 42 UU Perkawinan sebagai berikut:

"Anak yang sah adalah anak yang dilahirkan dalam atau sebagai akibat perkawinan yang sah."

Begitu pula pada Pasal 99 KHI disebutkan tentang anak sah, yaitu:

"Anak yang dilahirkan dalam atau akibat perkawinan yang sah dan/atau hasil perbuatan suami istri yang sah di luar rahim dan dilahirkan oleh istri tersebut."

Adapun yang disebut anak tidak sah adalah anak yang tidak dilahirkan sebagai suatu akibat dari perkawinan yang sah, biasanya disebut anak luar kawin. Anak, sebelum adanya li'an,

35 Fauzi Subhan, Wawancara, 20 Juni 2016.

36 Zainuddin Ali, Pelaksanaan Hukum Waris di Indonesia, (Jakarta: Sinar Grafika, 2010), 79. 
sebenarnya merupakan anak sah atau anak dalam perkawinan, karena dilahirkannya anak tersebut masih dalam suatu perkawinan yang sah antara kedua orang tuanya, terlepas dari anak itu hasil hubungan zina ibunya dengan laki-laki lain atau bukan.37 Adanya keraguan ayah terhadap anaknya itu, yang kemudian dilakukan sumpah li'an sebagai bentuk pengingkaran terhadap anak tersebut, membuat anak yang tadinya merupakan anak sah atau anak dalam kawin, menjadi anak tidak sah atau anak luar kawin. Menurut Hukum Islam, anak yang telah diingkari nasabnya oleh ayahnya tersebut termasuk ke dalam anak luar kawin golongan mulä'anah, yaitu anak yang dilahirkan oleh seorang wanita yang telah di-li'an oleh suaminya. Pengingkaran anak tersebut berdasarkan Pasal 102 KHI ayat (1) dan (2) dapat dilakukan dengan ketentuan:

"(1) Suami yang akan mengingkari seorang anakyang lahir dari istrinya, mengajukan gugatan kepada Pengadilan Agama dalam jangka waktu 180 hari sesudah hari lahirnya atau 360 hari sesudah putusnya perkawinan atau setelah suami itu mengetahui bahwa istrinya melahirkan anak dan berada di tempat yang memungkinkan dia mengajukan perkaranya kepada Pengadilan Agama. (2) Pengingkaran yang diajukan sesudah lampau waktu tersebut tidak dapat diterima."

Pada Pasal 43 ayat (1) UU Perkawinan menyebutkan:

"Anak yang dilahirkan di luar perkawinan hanya mempunyai hubungan perdata dengan ibunya dan keluarga ibunya."

Lebih lanjut pada pasal tersebut diterangkan, bahwa kedudukan anak luar kawin akan diatur lebih lanjut dalam Peraturan Pemerintah, namun sayangnya hingga kini pembuatan peraturan tersebut masih belum terwujud.

Jika ibu dianggap tidak layak atas hak asuh anak, maka hak asuh dapat dialihkan, karena hak asuh pertama diberikan kepada ibu, maka yurisprudensi mengutamakan perempuan daripada laki-laki. Kerabat ibu lebih diutamakan daripada kerabat ayah pada tingkat kerabat yang sama. Ulama

37 Fauzi Subhan, Wawancara, 20 Juni 2016. 
memberikan urutan dan skala prioritas hak pengasuhan anak kepada perempuan, sesuai dengan kemanfaatannya. Menurut para ulama, naluri kewanitaan mereka lebih cocok untuk mengasuh dan mendidik anak. Kesabaran wanita dalam menghadapi masalah hidup anak lebih tinggi dari pada kesabaran pria. Jika ibu tidak berhak mengurus dan tidak memenuhi syarat, sebagian ulama berpendapat, bahwa hak asuh dialihkan kepada bapak, karena nenek dari ibu adalah cabang, Pendapat lain yang dianggap lebih kuat mengatakan bahwa pengalihan hak orang tua kepada nenek di pihak ibu karena kedudukan ayah dalam hal ini urutan selanjutnya. 38.

Telah dipaparkan sebelumnya bahwa anak yang telah dili'an menjadi tidak memiliki hubungan kekeluargaan lagi dengan ayah yang me-li'an-nya dan nasab anak tersebut diserahkan kepada ibu yang melahirkannya. Kedudukan anak tersebut pun berubah, dari anak dalam perkawinan menjadi anak luar perkawinan. Terjadinya pengingkaran atas nasab anak tersebut, telah memutus hubungan kekeluargaan anak dengan ayah yang mengingkarinya, sehingga ayah tidak memiliki kewajiban apa pun terhadap anak tersebut. Selain terbebas dari kewajiban memberi nafkah seperti yang telah disebutkan pada Pasal 162 KHI, anak juga tidak lagi berhak mewaris dari ayahnya. Anakanak tersebut hanya dapat mewarisi dari ibu dan keluarga ibunya, sesuai dengan hadis Nabi Muhammad SAW sebagai berikut:

"Dari 'Amr ibn Syu'aib ra dari ayahnya dari kakeknya bahwa Rasulullah SAW bersabda: Setiap orang yang menzinai perempuan baik merdeka maupun budak maka anaknya adalah anak hasil zina, tidak mewarisi dan tidak mewariskan."

Selain anak yang dinasabkan kepada ibunya, salah satu akibat hukum li'an yang lain adalah diharamkannya suami istri tersebut untuk menikah kembali selama-lamanya. Akan tetapi, apabila ternyata suami terbukti telah berdusta pada saat pengucapan sumpah li'an maka keharaman itu menjadi hilang

38 Amir Syarifudin, Hukum Perkawinan Islam di Indonesia, (Surabaya: Prenada Media, 2006), 89. 
dan mereka diperbolehkan untuk menikah kembali. Hal ini sesuai dengan pendapat Imam Abu Hanifah dalam kitab Bada'i as- Shana'i:39

"Apabila suami mendustakan dirinya maka ia didera, atau istri mendustakan dirinya dengan membenarkannya maka membolehkan nikah antara keduanya dan berkumpul kembali."

Adapun yang menjadi dasar alasannya adalah:40

"Dan Abu Hanifah beralasan, karena suami telah mengaku dusta dalam tuduhannya, ini berarti li'an-nya batal, sebagaimana kepada suami boleh di-nisbat-kan anak kepadanya, begitu juga istrinya jika suami menginginkannya. Karena dasar haramnya untuk selamalamanya bagi mereka adalah semata-mata tidak dapat menentukan mana yang benar dari suami istri yang bermula'anah tersebut padahal sudah jelas salah satunya pasti ada yang berdusta. Karena itu jika telah terungkap rahasia tersebut maka keharaman selama-lamanya jadi terhapus."

Batalnya perceraian li'an antara suami istri karena kebohongan saat pengikraran sumpah tersebut mengakibatkan batal pulanya pengingkaran ayah terhadap nasab anaknya, sebab yang menjadi dasar dari pengingkaran itu adalah dengan adanya sumpah li'an. Telah batalnya sumpah li'an tersebut maka batal pulalah penasaban seorang anak kepada ibunya sebagai akibat li'an. Anak yang kembali dinasabkan kepada ayahnya tersebut menjadi berhak kembali untuk menggunakan nama ayahnya, berhak untuk dinafkahi oleh ayahnya, berhak mewaris dari ayah atau keluarga ayahnya, dan apabila anak tersebut adalah perempuan, maka ayah kembali berkewajiban untuk menjadi walinya. Semua hak-hak dan kewajiban antara ayah dan anak yang tadinya dihapus karena adanya li'an menjadi timbul kembali. Salah satu kewajiban seorang ayah tersebut tercantum dalam firman Allah surat At-Talak ayat 7, yaitu:

39 http://library.walisongo.ac.id/digilib/files/disk1/36/jtptiain-gdl-s12007-sasturi210-1777-2101059_-3.pdf, diakses tanggal 22 Juni 2020. 40 Ibid. 
"Hendaklah orang (ayah) yang mampu memberi nafkah menurut kemampuannya. Dan orang (ayah) yang rezekinya sempit hendaklah memberi nafkah dari harta yang diberikan Allah kepadanya. Allah tidak membebani seorang melainkan (sekadar) apa yang Allah berikan kepadanya. Allah kelak akan memberikan kelapangan sesudah kesempitan."

Berdasarkan hasil wawancara yang telah penulis lakukan dengan Hakim Subhan Fauzi di Kantor Pengadilan Agama Bandung, apabila terbukti bahwa suami telah berbohong pada saat pengucapan sumpah li'an, maka agar anak dapat dinasabkan kembali pada ayahnya, harus mengajukan permohonan ke pengadilan dengan perkara penetapan tentang asal-usul anak. Hal ini disebabkan karena, pada dasarnya perkara pokok dalam li'an adalah mengenai perceraian dan pengingkaran atau perubahan status pada anak tersebut hanya sebagai akibat hukum dari adanya perceraian li'an. Berkaitan dengan asal-usul anak ini diatur dalam Pasal 55 UU Perkawinan, yaitu:

(1) Asal-usul anak hanya dapat dibuktikan dengan akta kelahiran yang autentik, yang dikeluarkan oleh Pejabat yang berwenang;

(2) Bila akta kelahiran tersebut dalam ayat (1) pasal ini tidak ada maka Pengadilan dapat mengeluarkan penetapan tentang asal-usul seorang anak setelah diadakan pemeriksaan yang teliti berdasarkan buktibukti yang memenuhi syarat.

KHI pun juga mengatur perihal asal-usul anak ini, yaitu dalam Pasal 103 sebagai berikut:

(1) Asal-usul seorang anak hanya dapat dibuktikan dengan akta kelahiran atau alat bukti lainnya;

(2) Bila akta kelahiran alat bukti lainnya tersebut dalam ayat (1) tidak ada maka Pengadilan Agama dapat mengeluarkan penetapan tentang asal-usul seorang anak setelah mengadakan pemeriksaan yang teliti berdasarkan bukti-bukti yang sah. 
Hasil tes DNA merupakan salah satu alat bukti yang dapat dijadikan sebagai alat bukti lainnya sebagaimana dimaksud oleh Pasal 103 ayat (1) KHI, tentang pembatalan terhadap akta kelahiran dari masing-masing anak yang diingkari oleh ayahnya, sehingga akta kelahiran tidak dapat dijadikan sebagai alat bukti. Pada dasarnya, apabila terbukti suami telah berbohong pada saat pengucapan sumpah li'an dengan adanya hasil tes DNA tersebut maka menurut hukum anak tersebut sebenarnya merupakan anak sah yang lahir dalam perkawinan kedua orang tuanya. Oleh karena anak tersebut merupakan anak sah, dengan demikian penetapan asal-usul anak dapat dimintakan kepada Pengadilan Agama, bagi yang beragama Islam, setelah dilaksanakannya pemeriksaan yang teliti berdasarkan buktibukti yang sah.

Salah satu akibat hukum dari adanya perceraian li'an adalah putusnya hubungan perkawinan antara suami istri selamanya, sehingga perceraian ini termasuk dalam talak bā'in kubro dan dilarang untuk rujuk kembali. Namun jika ternyata pernyataan sumpah yang dibuat oleh suami tidak terbukti kebenarannya, maka perceraian karena li'an tersebut menjadi batal demi hukum. Perceraian dibatalkan karena li'an juga berarti penyangkalan anak oleh ayahnya sebagai akibat hukum dari cerai li'an. Anak menjadi ditegaskan kembali kepada ayahnya, sehingga memunculkan kembali hak dan kewajiban antara anak dan ayah. Ayah kembali berkewajiban untuk menghidupi anaknya dan menjadi wali, sedangkan anak berhak mewarisi dari ayah atau keluarga ayahnya. Pemulangan anak kepada ayahnya dapat diminta dengan mengajukan penetapan asal usul anak ke Pengadilan Agama.

\section{Penutup}

Anak sebelum adanya li'an sebenarnya merupakan anak sah atau anak dalam perkawinan karena dilahirkannya anak tersebut masih dalam suatu perkawinan yang sah hal ini diatur dalam Pasal 43 UU Perkawinan. Adanya keraguan ayah terhadap anaknya itu, yang kemudian dilakukan sumpah li'an sebagai bentuk pengingkaran terhadap anak tersebut, membuat anak yang tadinya merupakan anak sah atau anak dalam kawin 
menjadi anak tidak sah atau anak luar kawin. Menurut Hukum Islam, anak yang telah diingkari nasabnya oleh ayahnya tersebut termasuk ke dalam anak luar kawin golongan mula'anah, yaitu anak yang dilahirkan oleh seorang wanita yang telah di-li'an oleh suaminya. Pengingkaran anak tersebut berdasarkan Pasal 102 KHI ayat (1) dan (2). Hasil tes DNA merupakan salah satu alat bukti yang dapat dijadikan sebagai alat bukti lainnya sebagaimana dimaksud oleh Pasal 103 ayat (1) KHI, tentang pembatalan terhadap akta kelahiran dari masing-masing anak yang diingkari oleh ayahnya, sehingga akta kelahiran tidak dapat dijadikan sebagai alat bukti. Pada dasarnya, apabila terbukti suami telah berbohong pada saat pengucapan sumpah li'an dengan adanya hasil tes DNA tersebut maka menurut hukum anak tersebut sebenarnya merupakan anak sah yang lahir dalam perkawinan kedua orang tuanya. Oleh karena anak tersebut merupakan anak sah, dengan demikian penetapan asal-usul anak dapat dimintakan kepada Pengadilan Agama, bagi yang beragama Islam, setelah dilaksanakannya pemeriksaan yang teliti berdasarkan bukti-bukti yang sah.

\section{Daftar Pustaka}

Afifah, Nurul. "Qadzaf Menurut Hukum Islam dan KHI," Istinbath: Jurnal Hukum 12, no. 1 (2015)

Manan, Abdul. Penerapan Hukum Acara Perdata di Lingkungan Peradilan Agama. Yogyakarta: Kencana. 2016.

Agoes Dariyo, "Memahami Psikologi Perceraian dalam Kehidupan Keluarga", Jurnal Psikologi, 2, No. 2, 2004.

Al-Barry, Zakariya Ahmad. Hukum Anak-Anak dalam Islam. Jakarta: Bulan Bintang, 1997.

Ali, Zainuddin. Pelaksanaan Hukum Waris di Indonesia. Jakarta: Sinar Grafika. 2010.

Djubaedah, Neng. Perzinaan dalam Peraturan Perundangundangan di Indonesia Ditinjau dari Hukum Islam, Jakarta: Kencana, 2010.

Elimartati, Firdaus, "Hak Hadanah dalam Putusan Pengadilan", Jurnal Syariah, No. 2, Juli-Desember 2018.

Hafidzi, Anwar. Binti Musyarrofah. "Penolakan Nasab Anak Li'an dan Dhihar dengan Ta'liq (Analisis Komparatif Naskah 
Kitab Fiqh al-Islam wa Adillatuhu dengan al-Mughni)", Jurnal Ulul Albab, Vol. 1, No. 2, April 2018.

Hamid, Zahri. Pokok-pokok Hukum Perkawinan Islam dan Undang-Undang Perkawinan di Indonesia. Yogyakarta: Bina Cipta. 2002.

I. Doi, Abdur Rahman. Inilah Syariah Islam. Jakarta: Pustaka Panji Mas. 1991.

Kusmayanti, Hazar dkk. "Keabsahan Perkawinan Kuli Kawin di Desa Pamanukan Hilir Kabupaten Subang Dihubungkan dengan Undang-undang Perkawinan dan Hukum Islam". Suloh: Jurnal Fakultas Hukum Universitas Malikussaleh, Vol. 7, No. 2, April 2019.

, "Divorce Caused By Hypersexual Pshological Disorders In Husband", Jurnal Nurani, Vol. 19 No. 1 Desember, 2019. ---------, Eidy Sandra, Rijalullah Rahmatullah, “ Kebsahan Perkawinan Kuli Kawin di Desa Pamanukan Hilir Kabupaten Subang dihubungkan dengan Undang-undang Perkawinan No. 1 Tahun 1974 dan Hukum Islam", Suloh: Jurnal Fakultas Hukum Universitas Malikussaleh, Vol. 7, No. 2, April 2019.

Mahmud Mathlub, Abdul Majid. Panduan Hukum Keluarga Sakinah. Solo: Intermedia, 2005.

Majah, Ibnu. Sunan Ibnu Majah. juz 1 bab Talak, hadis ke-2018. Mansari, "Pertimbangan Hakim Memberikan Hak Asuh Kepada Ayah : Suatu Kajian Empiris di Mahkamah Syariah Banda Aceh", Jurnal Ar-raniry, Vol. 1 Nomor 1, April 2016.

Maswandi, "Asuh Anak yang Belum Dewasa Setelah Perceraian", JPPUMA: Jurnal Ilmu Pemerintahan dan Sosial Politik. Vol. 5 (1) 2017.

Munthe, Riswan. "Mengenai Kekuatan Sumpah Lian Menurut Fiqh Islam", Jurnal Penegakan Hukum, Vol 3, No 1 (2016). Muttaqin, Zainal. "Tinjauan Yuridis Perceraian Li'an Menurut Hukum Islam dan Undang-Undang No. 1 Tahun 1974 Tentang Perkawinan". Skripsi--Fakultas Hukum, UNPAD, 2013. 
Nurhasanah, "The Analysis of Causes of Divorce by Wives", The International Journal of Counseling and Education, Vol. 2 , 2017

Qolawun, Awy A.. Islam Q \& A: Dari Seks pada Rumah Tangga Hingga Bohong pada Suami, Jakarta: Mizania, 2015.

Rafiq, Ahmad. Hukum Islam di Indonesia, PT. RajaGrafindo, Jakarta, 2000.

Santoso, "Hakekat Perkawinan Menurut Undang-undang Perkawinan, Hukum Islam dan Hukum Adat, Yudisia, Vol. 7, No. 2, Desember 2016.

Soekanto, Soerjono. Pengantar Penelitian Hukum. Jakarta: UIPress, 2011.

Soimin, Soedharyo. "Hukum Orang dan Keluarga: Perspektif Hukum Perdata Barat/ BW, Hukum Islam, dan Hukum Adat". Jakarta: Sinar Grafika. 2002.

Suryani. "Lian dalam Perpektif Filosofis dan Normatif", Jurnal Pemikiran Keislaman dan Tafsir Hadist, Vol 5, No 1 (2016) Syarifudin, Amir. Hukum Perkawinan Islam di Indonesia, Surabaya: Prenada Media, 2006.

Usman, Suparman. Hukum Islam Asas-Asas dan Pengantar Studi Hukum Islam dalam Tata Hukum Indonesia. Jakarta: PT. Gaya Media Pratama. 2001.

Zaisika, https://media.neliti.com/media/publications/14077ID-perceraian-karena-lian-dan-akibat-hukum-dalamperspektif-fiqih-islam-dan-kompila.pdf, diakses $(01 / 11 / 2020)$ 